\title{
Cross-examining the effectiveness of e-advocacy as a tool for advancing women's rights in Nigeria
}

\section{Rosemary O. Popoola*, Egharevba Matthew and Oluyemi Fayomi}

College of Leadership Development Studies,

College of Business and Social Sciences (CBSS),

Department of Political Science and International Relations,

Department of Sociology,

Covenant University,

Ogun State, 2348064010967, Nigeria

Email: rosemary.popoola@covenantuniversity.edu.ng

Email: matthew.egharevba@covenantuniversity.edu.ng

Email: nike.fayomi@covenantuniversity.edu.ng

${ }^{*}$ Corresponding author

\begin{abstract}
Following the alleged success of social media in the Arab Spring and other social change activities around the world, there has been increasing interest in the capacity of electronic advocacy also known as digital activism to translate to social change. Yet, scholars remain divided about the effectiveness of electronic advocacy in driving social change. Does electronic advocacy promote social change, or does it result in slacktivism? Using the survey method for data obtained from a convenient sample of residents of Lagos and Ogun states in Southwestern Nigeria, this study examined effectiveness electronic advocacy on women-centred issues and the extent to which it leads to social change or mere slacktivism. This study revealed that digital activism is capable of leading to the promotion of women-centred issues but is not helpful in the protection of women's issues and in driving social change.
\end{abstract}

Keywords: electronic; digital activism; feminism; advocacy; women; gender and governance.

Reference to this paper should be made as follows: Popoola, R.O., Matthew, E. and Fayomi, O. (2020) 'Cross-examining the effectiveness of e-advocacy as a tool for advancing women's rights in Nigeria', Int. $J$. Electronic Governance, Vol. 12, No. 4, pp.367-386.

Biographical notes: Rosemary O. Popoola holds a $\mathrm{PhD}$ in International relations from Covenant University Ota Nigeria. She researches the various intersection of advocacy with feminism, gender, women, technology and environment.

Egharevba Matthew is an Associate Professor in the Department of Sociology at Covenant University Ota Nigeria.

Oluyemi Fayomi is an Associate Professor in the Department of Political Science and International Relations at Covenant University Ota Nigeria. 


\section{Introduction}

On 14 April 2014, the world was awakened to the news that over 276 female students had been kidnapped from Government Girls' Secondary School, Chibok in Borno State, Nigeria. In a video released on 5 May, 2014, the Islamic Jihadist group, Boko Haram, based in the northeastern part of Nigeria claimed responsibility for the kidnap. The reaction that followed this news, among others, gave birth to several hashtag on social media, the most prominent of them being BringBackOurGirls (BBOG). This online activism had celebrities, world leaders, activists and citizens around the world using the hashtag \#BringBackOurGirls. In less than three months after the hashtag campaign began, more than 4 million tweets had been sent using the \#BringBackourGirls hashtag, while 57,000 re-tweets had been recorded from users tweeting from around the world, thus, leading to increasing awareness about the abduction and public outcry to free the girls (Emma, 2015). Five years after the abduction of the girls, over 112 of the girls are still missing with controversy about how many were released or rescued.

More so, on 19th February 2018, another group of girls was kidnapped from Government Girls' Science Technical College (GGSTC), Dapchi, Yobe State by the same Islamic fundamentalist group-Boko Haram-that abducted the Chibok girls almost four years earlier. As at 28th March 2018, 106 out of the 110 students were released after a controversial negotiation with the terrorist group. Five of the girls were said to have died in captivity while one of the students, Leah Sharibu, was held in captivity by the insurgents because she refused to convert from Christianity to Islam as the insurgents demanded. Activists and citizens around the world embarked on an online campaign hashtagged \#FreeLeahSharibu. It has been over 365 days since her abduction yet, her release is not in view.

In between these two cases, there were several digital activism endeavours aimed at different social issues, but one of the most popular of them is \#FindShonde hashtag. This online activism in 2016 involved Lekan Shonde, a dockworker, who killed his banker wife, Ronke (aged 36), at their residence in Egbeda, Lagos and then absconded. Activists started an online campaign to find him and also raise awareness about domestic violence. Days after, with increasing awareness and law enforcement efforts, he was found. Three years after, in March 2019, a High Court in Ikeja, Lagos found him guilty and sentenced him to death by hanging. This case and the two others earlier mentioned have continued to raise questions about the effectiveness of digital activism in bringing about social change. To what extent do citizens engage with digital activism in Nigeria on women issues? How effective is citizen's digital activism on women issues? Hence, using a thematic review model, the study employed a mixed method design augmented by a structured questionnaire, focus group discussions, and interview guide to elicit information from a convenient sample drawn from residents of Lagos and Ogun states in Nigeria on the perception of the effectiveness of e-advocacy as a tool for advancing women's rights.

\section{Literature review}

Over the last two decades, citizens around the world have become increasingly enamoured with, and interested in, the expanding use of digital technologies-mobile phones and internet-enabled devices, in campaigns for social and political change (Joyce, 
2010; Sivitanides and Shah, 2011; Outshoorn, 2012). The alleged 'success' of new media in the Arab Spring and other digital activism endeavours, such as Kony2012, have sparked significant interest in digital activism. Yet, scholars remain divided about the effectiveness of digital activism in driving social change. Does digital activism promote social change, or does it result in slacktivism?

Proponents of digital activism have argued that it has improved interactivity, heightened awareness, and facilitated mass mobilisation. It has led to the democratisation of communication by removing the censorship that exists around communication in most state-controlled media in authoritarian societies. Digital activism has allowed social movements and ideas about social justice to spread organically to individuals and organisations that share similar ideas (Saxton et al., 2015). Sara (2015) posited that digital technology has allowed people to share, like, and spread news statutes and information at rapid speed. She further argues that digital activism has revolutionised Arab women's struggle for equality. Specifically, it has empowered women in the Arab world to call for legislative change, confront sexual harassment, gender-based violence, condemn patriarchy and religious conservatism. Digital activism has been used to confront authoritarian regimes, inspired several protests and actions, it has prompted civic organising with domino effect. It has equipped people to push for action for social causes round the world, recruit activists, generate global and media attention on social and political issues, put pressure on government and policy makers, as well as created citizen-centred journalism. Norris (2004) argued that digital activism reduces participation costs, promotes collective identity, and creates a sense of community that transcends national boundaries (Harlow and Guo, 2014). Studies have further affirmed the benefits of digital activism in several contexts and in relation to several issues.

However, while proponents laud the potentials, possibilities, and benefits of digital activism, critics of digital activism opine among other things that digital activism promotes slacktivism. The term, 'slacktivism', is derived from two words, "slacker" and 'activism', and is usually used to describe civic or political online activities that carry little social and political benefits (Breuer and Farooq, 2012). Critics claim that digital activism places slacktivism or "arm-chair activism" at the detriment of traditional activism which requires personal sacrifice and result-oriented activism. Simply stated, digital activism is a modern window dressing for traditional forms of organising.

Budish (2012) opined that digital activism oversimplifies complex situations as compound and intricate issues are reduced to slogans and memes, it endangers activists, and still requires traditional activism to work. In no other situation was this more exemplified than in the Kony2012 case and in studies on the Arab Spring. Kony2012 was a viral video created by Invisible Children - a US based advocacy group focused on bringing brutal Ugandan warlord, Joseph Kony, to justice. This professionally edited video was acclaimed to have reached 100 million views on YouTube in six days. Despite the success of the video in creating awareness about war crimes and use of child soldiers, it oversimplified the complexity of the Ugandan crisis. According to Ethan Zuckerman, Director of MIT's Center for Civic Media, the video drastically oversimplified the conflict in Uganda to "a single bad guy, a single threat to eliminate" which "leads to an unworkable solution". Specifically, critics have argued that hashtags oversimplify the contexts of the injustices they describe (Gay, 2013; Goldberg, 2014; Murphy, 2013). Digital activism may 'cheapen' civic engagement and commitment by engaging supporters in low-cost efforts, dispiriting the public, and crowd-out higher level engagement (Scott and Maryman, 2016). 
Despite its acclaimed transformative and democratising potential, digital activism does not always translate to real time change. Lewis et al. (2014), in their study on how the Save Darfur campaign was able to facilitate recruitment and donation for the Save Darfur cause on Facebook, found that the most popular social network site in the world contributed less to recruiting and facilitating donation. The study concluded that in the case of the Save Darfur campaign, Facebook conjured an illusion of activism rather than facilitating the real thing. Similarly, Harlow and Guo (2014), in their study of the impact of digital communication technology on immigrant activism, found that digital technologies are perhaps pacifying would-be activists, convincing them they are contributing more than they actually are. Thus, 'slacktivism' or 'clicktivism' that takes just a mouse click is potentially diluting 'real' activism. More so, contrary to mainstream studies that give absolute credit to digital activism in the Arab Spring, studies like Tufekci and Wilson (2012) and Lim (2012) have pointed out the role of some forms of traditional activism, for example, myriads of workshops and conferences, word-of-mouth through taxi cab drivers, face-to-face interactions, in-person connections and communication, as the critical foundation for the social change in North Africa. Morozov (2011) posited that those in the West particularly have a 'net delusion' that is defined by internet-centrism and cyber-utopianism that obscure an evolving internet landscape that may actually stall or hinder democratic possibilities.

However, while digital activism is generally contested, its effectiveness in social change for women-centred issues remains underdeveloped. Although significant studies on women's issues and digital technology are evolving: use of social media by women (Oyesomi et al., 2014); women's safety online (Nwammuo, 2013); digital technology and women's body image (Fardouly and Vartanian, 2015; Tiggemann and Miller, 2010; Tiggemann and Slater, 2013; Fardouly et al., 2015), there are scanty studies that examine citizens' engagement with digital technologies for issues centred on women's rights. Empirical studies on online activism are surprisingly scarce (Lewis et al., 2014). A rigorous search of leading electronic journal databases including Google Scholar, EBSCO, AJOL and Sage suggests that no academic research has been done to ascertain whether or not citizens' engagement with digital activism on women-centred issues in Nigeria leads to social change or slacktivism. Against this background, this study examines the level of Nigerians citizens' engagement with digital activism on womencentred issues and their perception of its effectiveness in bringing about social change or otherwise. The goal is to affirm or refute scholarly contentions on whether citizens' engagement with digital activism translates to social change or slacktivism.

Studies have looked at the effectiveness or otherwise of BBOG in isolation, without paying attention to the context within which it took place. However, as significant as these studies are, they glossed over the fact that the effectiveness or otherwise of BBOG was not independent of the realities of past and present digital activism on womencentred issues. Digital activism takes place within a context of socio-economic and political realities that work in complementary, or sometimes, contradictory relationship to improve or abate digital activism. More so, BBOG rode on an already existent digital activism culture on women-centred issues whose effectiveness or ineffectiveness has been under-researched. Though under-researched, the culture provided the platform and gave momentum to BBOG and other digital activism movements. This study examines this digital activism culture in terms of citizens' engagement online, issues discussed online, frequency of engagement, amongst others. The findings of this study will be useful to policy makers and women activists as they strategise on which advocacy 
mechanism to engage, whether traditional or digital. Significantly, this study makes significant contribution to scholarship on digital activism and women-centred issues in the Global South, specifically Nigeria, an area of scholarship that is largely underdeveloped. The remainder of the paper is structured as follows: The next section provides description of study area, the methods of the study; this is followed by the results and findings of the study and the last section concludes with the summary of the study, the study's research contribution, and directions for future research.

\section{Description of area of study}

Nigeria has six geo-political zones namely north-central, north-east, north-west, southeast, south-south, and south-west. The south west geopolitical zone comprises six states; Ekiti, Lagos, Ogun, Ondo, Osun and Oyo. The entire zone has a population of about $27,581,992$ based on the 2006 population census figures, although the population may have increased and has a combined police strength of 67,757 officers and men. Two states in south-west specifically Lagos and Ogun were selected for the study using simple random sampling. Lagos state according to the 2006 National Population Census figure has an estimated population of about 9,013,534 covering the 20 local government areas while Ogun state has an estimated population of 3,728,089 with 20 local government area (Nigeria Police Force, 2016).

\section{Methods}

The study employed a mixed method design augmented by a structured questionnaire, focus group discussions, and interview guide to elicit information from a convenient sample drawn from residents of Lagos and Ogun states in Nigeria. The study engaged mixed methods of data collection. These include primary and secondary sources of data collection. Primary data was sourced using questionnaire, in-depth interview and Focused Group Discussion. The questionnaire is a combination of structured and unstructured questions. The structured questions had multiple choice answers on a five-point Likert scale.

The interviews and Focus Group Discussion with key stakeholders involved in women's rights advocacy such as non-governmental organisations, women's rights activists, and experts on the subject. These categories of respondents were purposively selected because they possess vast knowledge and experience in women's rights and can provide responses to the research questions raised in this study. The interviews were captured using a video recorder where it does not violate any ethical principles and the recorded sessions were transcribed and analysed by the researcher. Secondary data were obtained from library resources such as textbooks, journals, government, official documents, newspapers, seminars, workshop papers, and the internet. The researcher conducted interviews with the following key informants; Dr. Joe Odumakin of Women Arise; Barrister Titi Akosa of $21^{\text {st }}$ Century Issue; Dr. Princess Olufemi Kayode of Media Concern; Ify Bredan-Ndukwu of Women and Children's Rights Development Centre $\{$ WOCHRID ; Gbenga Sesan of Paradigm Initiative Nigeria; Mr. Toyin Oloniteru of Spindlar Cyberlaw Centre; Mrs Doyin Ogunbiyi, Former Commissioner for Women Affairs, Ogun state. 
The population of the study comprises of men and women between the age of 18-60 that are educated with a minimum qualification of secondary school certificate or its equivalent. This group is chosen for several reasons. First, 18 is the age that one attains suffrage rights and 60 is the minimum age of retirement. Secondly, it is expected that people within this age group are more likely to be aware of their rights and likely to recognise when they are being violated. Thirdly, a larger proportion of the youth population in the country fall within this age group. The sample size of 384 was drawn for each of the two states and summing it up gives sample size of 768 . This sample size is for questionnaire respondents. The justification for this sample size was based on Krejcie and Morgan 1970 sample size determinant. According to Krejcie and Morgan (1970) for a population which is equal to or greater than 1,000,000, the required sample size is 384 . Thus, a sample size of 768 was drawn from a population. This sample size was drawn from population of the two states based on 2006 population census. Below is the sample size equation and Table 1 is the analysis of the copies of questionnaire used in the study.

$$
S P=\frac{N X S}{T P}
$$

where $S P$ is the sample population, $N$ is population size of the RNS, $S$ is sample size and $T P$ is the total population.

Table 1 Analysis of copies of questionnaire

\begin{tabular}{lcccccc}
\hline & \multicolumn{2}{c}{ Administered } & \multicolumn{2}{c}{ Returned } & \multicolumn{2}{c}{ Analysed } \\
\cline { 2 - 7 } & No. & $\%$ & No. & $\%$ & No. & $\%$ \\
\hline Lagos state & 384 & 100 & 430 & $95 \%$ & 405 & $90 \%$ \\
Ogun state & 384 & 100 & 230 & $62.5 \%$ & 209 & $56 \%$ \\
Total & 768 & 100 & 630 & & & \\
\hline
\end{tabular}

Source: Fieldwork (2017)

\section{Method of data analysis}

The quantitative data was analysed using simple percentage, frequency distribution and tabular representation where necessary. Logistic regression, cross tabulation, chi-square were used to analyse the data with the use of Statistical Package for Social Sciences (SPSS) version 21 and SAS. Qualitative data gathered from interviews and Focus Group Discussions, was transcribed and subjected to thematic analysis and narrative techniques was employed where necessary.

\section{Results}

Table 2 presents the demographic representations of respondents; age, sex, educational background, working status and residence of the respondents. 
Table 2 Distribution of respondents' socio-demographic characteristics

\begin{tabular}{llcr}
\hline & Classification & Frequency & Percentage \\
\hline Sex & Male & 174 & 28.3 \\
& Female & 440 & 71.7 \\
Age & Total & 614 & 100.0 \\
& 18-28 years & 125 & 20.4 \\
& 29-39 years & 199 & 32.4 \\
& 40-50 years & 239 & 38.9 \\
Education & 51 years and above & 51 & 8.3 \\
& Total & 614 & 100.0 \\
& SSCE & 60 & 9.8 \\
& BSc and its equivalent & 459 & 74.8 \\
& Postgraduate & 83 & 13.5 \\
& Other professional qualification & 12 & 2.0 \\
Torking status & 614 & 100.0 \\
& Total & 416 & 67.8 \\
& Employed & 77 & 12.5 \\
& Not employed & 1 & 0.2 \\
& Housewife & 102 & 16.6 \\
& Self-employed & 18 & 2.9 \\
& Employer & 614 & 100.0 \\
& Total & 405 & 66.0 \\
& Lagos State & 209 & 34.0 \\
& Ogun State & 614 & 100.0 \\
\hline
\end{tabular}

Source: Author's computation with SPSS (2017)

The result of the frequency distribution of the respondents by age in Table 2 shows there are $174(28.3 \%)$ male respondents and 440 (71.7\%) female respondents. This indicates that most of the respondents were females. Analysis of the respondents' age shows that $125(20.4 \%)$ were between the ages of 18-28 years, 199(32.4\%) were within the age bracket of 29-39 years, 239(38.9\%) fall within the age group of 40-50 years while the remaining set $51(8.3 \%)$ were found 60 years. In essence, it could be seen that the respondents consist mostly of matured persons who are knowledgeable about women rights advocacy and fall within the age category of 40-50 years.

The educational distribution of the participants indicates the sampled population consists of $60(9.8 \%)$ SSCE holders, 459 (74.8\%) BSc and its equivalent, $83(13.5 \%)$ had attained postgraduate education while $12(2.0 \%)$ had other professional qualifications. Hence, the largest proportion of the sample observation were degree holders (BSc) and its equivalent. The analysis of the participants by working status shows those employed $416(67.8 \%)$ constitutes the largest proportion, unemployed $77(12.5 \%)$, housewife $1(0.2 \%)$, self-employed $102(16.6 \%)$ and employers of labour were $18(2.9 \%)$. The distribution of respondents by residence indicates that the majority 
$405(66.0 \%)$ were those resident in Lagos while the remaining 209 (34.0\%) reside in Ogun state.

Table 3 shows the relationship between advocacy tools and women's rights promotion. The result from the table indicated a significant direct correlation (correlation coefficient $(R)=0.884 ; P$-value $<0.01)$; chi-square $\left(X^{2}=598.907 ; P\right.$-value $\left.<0.01\right)$ between most effective e-advocacy tools and respondents' familiarity with e-advocacy. The evidence from the result shows that 436 (92.4\%) of the participants that chose social media as the most effective e-advocacy tool were equally familiar with the use of social media. Detailed analysis of the result reveals that another 7 (70.0\%), 1 (33.3), $2(40.0 \%)$ and $1(0.9 \%)$ of the participants who believed that social media as the most effective e-advocacy tool were also familiar with email, blog, website and other e-advocacy tools respectively. Four (0.8) from the email and blog platform, 5(1.1\%) from other digital and $23(4.9 \%)$ who subscribed to all media indicated familiarity with social media.

Table 3 Data on Nigerian public engagement with e-advocacy on women's rights promotion

\begin{tabular}{|c|c|c|c|c|c|c|}
\hline \multirow[b]{2}{*}{ Variable } & \multicolumn{6}{|c|}{ Most effective e-advocacy tool } \\
\hline & $\begin{array}{l}\text { Social } \\
\text { media }\end{array}$ & $\begin{array}{l}\text { Emails } \\
\text { and blog }\end{array}$ & Digitals & $\begin{array}{c}\text { All } \\
\text { media }\end{array}$ & Others & Total \\
\hline $\begin{array}{l}\text { Familiarity with } \\
\text { e-advocacy tool }\end{array}$ & Freq. (\%) & $\begin{array}{l}\text { Freq. } \\
(\%)\end{array}$ & $\begin{array}{l}\text { Freq. } \\
(\%)\end{array}$ & $\begin{array}{l}\text { Freq. } \\
(\%)\end{array}$ & Freq. (\%) & Freq. (\%) \\
\hline Social media & $436(92.4)$ & $4(0.8)$ & $5(1.1)$ & $23(4.9)$ & $4(0.8)$ & $472(100)$ \\
\hline Email & $7(70.0)$ & $1(10.0)$ & $0(0)$ & $2(20.0)$ & $0(0)$ & $10(100)$ \\
\hline Blog & $1(33.3)$ & $0(0)$ & $1(33.3)$ & $1(33.3)$ & $0(0)$ & $3(100)$ \\
\hline Website & $2(40.0)$ & $0(0)$ & $0(0)$ & $2(40.0)$ & $1(20.0)$ & $5(100)$ \\
\hline \multirow[t]{2}{*}{ Others } & $1(0.9)$ & $1(1.7)$ & $0(0)$ & $4(3.5)$ & $108(93.9)$ & $115(100)$ \\
\hline & \multicolumn{6}{|c|}{$X^{2}=598.907(0.000) ;$ Correlation coefficient $(R)=0.884(0.000)$} \\
\hline \multicolumn{7}{|l|}{$\begin{array}{l}\text { Mostly engaged } \\
\text { e-advocacy tools }\end{array}$} \\
\hline Social media & $410(93.8)$ & $4(0.9)$ & $3(0.7)$ & $18(4.1)$ & $2(0.5)$ & $437(100)$ \\
\hline Email & $7(70.0)$ & $2(20.0)$ & $0(0)$ & $0(0)$ & $1(10.0)$ & $10(100)$ \\
\hline Blog & $1(50.0)$ & $0(0)$ & $0(0)$ & $1(50.0)$ & $0(0)$ & $2(100)$ \\
\hline Website & $2(40.0)$ & $0(0)$ & $2(40.0)$ & $1(20.0)$ & $0(0)$ & $5(100)$ \\
\hline \multirow[t]{2}{*}{ Not involved } & $26(17.6)$ & $1(0.7)$ & $1(0.7)$ & $11(7.4)$ & $109(73.6)$ & $148(100)$ \\
\hline & \multicolumn{6}{|c|}{$X^{2}=528.834(0.000) ;$ Correlation coefficient $(R)=0.798(0.000)$} \\
\hline \multicolumn{7}{|c|}{$\begin{array}{l}\text { Reduction in women's right } \\
\text { violation by } \\
\text { e-advocacy usage }\end{array}$} \\
\hline Strongly disagree & Nil & Nil & Nil & Nil & Nil & Nil \\
\hline Disagree & $1(100)$ & $0(0)$ & $0(0)$ & $0(0)$ & $0(0)$ & $1(100)$ \\
\hline Undecided & $22(75.9)$ & $0(0)$ & $1(3.4)$ & $4(13.8)$ & $2(6.9)$ & $29(100)$ \\
\hline Agree & $312(84.1)$ & $3(0.8)$ & $3(0.8)$ & $21(5.7)$ & $32(8.6)$ & $371(100)$ \\
\hline \multirow[t]{2}{*}{ Strongly Agree } & $95(51.9)$ & $4(2.2)$ & $2(1.1)$ & $8(4.4)$ & $74(40.4)$ & $183(100)$ \\
\hline & \multicolumn{6}{|c|}{$X^{2}=94.988 ;(0.000) R=0.313(0.000)$} \\
\hline
\end{tabular}


Table 3 Data on Nigerian public engagement with e-advocacy on women's rights promotion (continued)

\begin{tabular}{|c|c|c|c|c|c|c|}
\hline \multirow[b]{2}{*}{ Variable } & \multicolumn{6}{|c|}{ Most effective e-advocacy tool } \\
\hline & $\begin{array}{l}\text { Social } \\
\text { media }\end{array}$ & $\begin{array}{l}\text { Emails } \\
\text { and blog }\end{array}$ & Digitals & $\begin{array}{c}\text { All } \\
\text { media }\end{array}$ & Others & Total \\
\hline \multicolumn{7}{|c|}{$\begin{array}{l}\text { Use of e-advocacy for } \\
\text { highlighting women's right } \\
\text { violation }\end{array}$} \\
\hline Strongly agree & Nil & Nil & Nil & Nil & Nil & Nil \\
\hline Disagree & Nil & Nil & Nil & Nil & Nil & Nil \\
\hline Undecided & $22(66.7)$ & $0(0.0)$ & $2(6.1)$ & $5(15.2)$ & $4(2.1)$ & $33(100)$ \\
\hline Agree & $250(78.1)$ & $3(0.9)$ & $2(0.6)$ & $17(5.3)$ & $48(15.0)$ & $320(100)$ \\
\hline \multirow[t]{2}{*}{ Strongly agree } & $156(69.3)$ & $4(1.8)$ & $2(0.9)$ & $10(4.4)$ & $53(23.6)$ & $225(100)$ \\
\hline & \multicolumn{6}{|c|}{$X^{2}=23.475(0.000) ; R=0.042(0.098)$} \\
\hline
\end{tabular}

Majority of the participants amounting to 410 (93.8\%) perceived social media as the most effective e-advocacy tool. Other details of the result show that $7(70.0 \%), 1(50.0 \%)$, $2(40.0 \%)$ of the participants who acknowledged social media as the most effective e-advocacy tool were mostly used in email, blog and website respectively. However, $26(17.6 \%)$ of social media users and $109(73.6 \%)$ that preferred other media claimed they were not involved in the use of e-advocacy tools. Also $4(0.9 \%), 3(0.7 \%), 18(4.1 \%)$ and $2(0.5 \%)$ respondents who respectively recognised emails and blog, Thus, a significant level of association $\left(R=0.798 ; P\right.$-value $\left.<0.01 ; \mathrm{X}^{2}=528.834\right)$ was established between e-advocacy tools' engagement by participants and its effectiveness.

The result of the relationship between most effective e-advocacy tool and reduction in women's rights violation suggests a significant correlation $(R=0.313 ; P$-value $<0.01$; $X^{2}=94.988 ; P$-value $\left.<0.01\right)$. It could be observed that only $1(100 \%)$ of the respondents who subscribed to social media as the most effective e-advocacy tool disagreed with the reduction in women's rights violation. Further information from the table shows that $22(75.9 \%)$ of the respondents that believed that social media as the most effective e-advocacy tool were undecided in the reduction of women's rights violation, a larger proportion of the respondents $312(84.1 \%)$ agreed while the rest $95(51.9 \%)$ strongly agreed on the reduction in women's rights violation. Some of the respondents $4(2.2 \%)$ who subscribed to emails and blog as the most effective e-advocacy tool strongly agreed that there is reduction in women's right violation. $3(0.8 \%), 21(5.7 \%)$ and $32(8.6 \%)$ of the respondents on digital platforms, all media and others respectively agreed on reduction in women's rights violation. On use of e-advocacy for women's rights promotion, 22 $(66.7 \%)$ of the respondents were undecided, the largest proportion $250(78.1 \%)$ were in support of the effectiveness of e-advocacy in highlighting incidences of violation of women's rights and this was strongly supported by another $156(69.3 \%)$ of the respondents. The result shows that $4(1.8 \%), 2(0.9 \%), 10(4.4 \%)$ and $53(23.6 \%)$ of the participants on email and blogs, digitals, all media and other advocacy tools strongly agreed with the use of e-advocacy in highlighting violation of women's rights respectively. The analysis of the result shows an existence of a weak positive correlation $\left(R=0.042 ; \quad P\right.$-value $<0.10 ; \quad X^{2}=23.475 ; \quad P$-value $\left.<0.01\right)$ between most effective 
e-advocacy tools and use of e-advocacy in highlighting incidence of violation of women's rights.

The analysis of the relationship between most effective e-advocacy tools used in women's rights promotion and the viability of e-advocacy tools is as shown in Table 3 . The result of the table shows a significant level of association (correlation coefficient $(R)=0.429$; p-value $<0.01$; chi-square $\left(X^{2}=180.988 ; P<0.01\right)$ between the viability of e-advocacy tools and the most effective e-advocacy tool. Detailed analysis of the result shows that majority $122(91.0 \%)$ of the respondents who subscribed to social media as their most effective e-advocacy tool also saw the viability to be highly effective, and 133 $(82.6 \%)$ believed the viability of e-advocacy is effective. Furthermore, $134(74.4 \%)$ of the social media subscribers were undecided on the issues of viability of e-advocacy tool, $30(47.6 \%)$ of the social media subscribers perceived the viability of e-advocacy to ineffective, while $2(6.1 \%)$ claimed it is highly ineffective. Email subscribers $3(2.2 \%)$, all media $7(5.2 \%)$ and other subscribers $2(1.5 \%)$ also confirmed the viability of eadvocacy to be highly effective.

Table 4 shows that there is a significant relationship $(R=0.215 ; p<0.01$ chi-square $\left(\mathrm{X}^{2}=89.216 ; \quad P<0.01\right)$ between the use of e-advocacy by non-governmental organisations (NGOs) in promoting women's rights and most effective e-advocacy tool. Evidently, 94 (74.6\%) of the participants who subscribed to social media were undecided about the use of e-advocacy by NGOs in the promotion of women's rights though majority of the participants $271(84.7 \%$ ) on social media platforms agreed to the usage of e-advocacy by the NGO's and were strongly supported by the remaining $63(46.7 \%)$ on the same platform. A closer observation of the result shows that $4(3.0 \%)$ subscribers to the emails and blogs strongly attested to the use of e-advocacy by NGOs, $4(1.3 \%)$ of the digital subscribers and $18(5.6 \%)$ of all media subscribers agreed, while 55(40.7\%) users of other e-advocacy tools strongly supported the use of e-advocacy by NGOs. The participants' frequent usage of E- advocacy tools and the most effective e-advocacy tools reveal a significant correlation $(R=0.543 ; P$-value $<0.01)$; chi-square $\left(X^{2}=250.352\right.$; $P$-value $<0.01)$.

The result of the analysis indicates that $136(93.2 \%)$ of the respondents who always resorted to e-advocacy tools were on social media, $156(93.4 \%)$ of the social media respondents sometimes used e-advocacy tools, $110(67.5 \%)$ were doing so once in a while to promote women's rights, while $18(26.5 \%)$ on the social media, $3(4.4 \%), 4(5.9 \%)$ and $42(61.8 \%)$ on emails and blogs, digitals, all media and other channels respectively never used them as advocacy tools.

On the basis of issues discussed on social media in relation to advocacy on women's right, $66(75.0 \%)$ of the participants who subscribed to social media as the most effective e-advocacy tool discussed issues on women's civil and political rights, $103(66.0 \%)$ focused on women's economic rights, $32(72.7 \%)$ were on women's social rights, majority 145 (78.0\%) concentrated on women's cultural rights, while $71(78.0 \%)$ were on other matters. Further analysis of the result suggests that 5(5.7\%) of the emails and blog users dwelt more on women's civil and political rights, 3(1.6) of the digital users and $12(6.5 \%)$ of all media users focused their discussion on cultural rights of women and $45(28.8 \%)$ users of other advocacy tools concentrated more economic rights. It could also be observed that a significant positive correlation $(R=0.072) ; P$-value $<0.10)$; $X^{2}=39.157 ; p$-value $\left.<0.01\right)$ existed between social media usage in discussing issues on women's rights and the most effective e-advocacy tool. 
Table 4 Data on Nigerian public perception of the effectiveness of e-advocacy tools in the promotion of women's rights

\begin{tabular}{|c|c|c|c|c|c|c|}
\hline \multirow[b]{2}{*}{ Variable } & \multicolumn{6}{|c|}{ Most effective e-advocacy tool } \\
\hline & $\begin{array}{l}\text { Social } \\
\text { media }\end{array}$ & $\begin{array}{l}\text { Emails } \\
\text { and blog }\end{array}$ & Digitals & All media & Others & Total \\
\hline Viability of e-advocacy & Freq. (\%) & Freq. (\%) & Freq. (\%) & Freq. (\%) & Freq. (\%) & Freq. (\%) \\
\hline Highly effective & $122(91.0)$ & $3(2.2)$ & $0(0)$ & $7(5.2)$ & $2(1.5)$ & $134(100)$ \\
\hline Effective & $133(82.6)$ & $1(0.6)$ & $2(1.2)$ & $11(6.8)$ & $14(8.7)$ & $161(100)$ \\
\hline Undecided & $134(74.4)$ & $1(0.6)$ & $2(1.1)$ & $10(5.6)$ & $33(18.3)$ & $180(100)$ \\
\hline Ineffective & $30(47.6)$ & $1(1.6)$ & $2(3.2)$ & $2(3.2)$ & $28(44.4)$ & $63(100)$ \\
\hline \multirow[t]{2}{*}{ Highly ineffective } & $2(6.1)$ & $1(3.0)$ & $0(0)$ & $1(3.0)$ & $29(87.9)$ & $33(100)$ \\
\hline & \multicolumn{6}{|c|}{$X^{2}=180.988(0.000) ;$ Correlation coefficient $(R)=0.429(0.000)$} \\
\hline \multicolumn{7}{|c|}{ Use of e-advocacy by NGO's } \\
\hline Undecided & $94(74.6)$ & $1(0.8)$ & $2(1.6)$ & $2(1.6)$ & $27(21.4)$ & $126(100)$ \\
\hline Agree & $271(84.7)$ & $2(0.6)$ & $4(1.3)$ & $18(5.6)$ & $25(7.8)$ & $320(100)$ \\
\hline Strongly agree & $63(46.7)$ & $4(3.0)$ & $0(0)$ & $13(9.6)$ & $55(40.7)$ & $135(100)$ \\
\hline & \multicolumn{6}{|c|}{$X^{2}=89.216(0.000) ; R=0.215(0.000)$} \\
\hline \multicolumn{7}{|c|}{ Respondent's use of e-advocacy tools } \\
\hline Always & $136(93.2)$ & $0(0)$ & $1(0.7)$ & $8(5.5)$ & $1(0.7)$ & $146(100)$ \\
\hline Sometimes & $156(93.4)$ & $1(0.6)$ & $2(1.2)$ & $4(2.4)$ & $4(2.4)$ & $167(100)$ \\
\hline Once in a while & $110(67.5)$ & $0(0)$ & $2(1.2)$ & $16(5.9)$ & $35(21.5)$ & $163(100)$ \\
\hline \multirow[t]{2}{*}{ Never use it } & $18(26.5)$ & $3(4.4)$ & $1(1.5)$ & $4(5.9)$ & $42(61.8)$ & $68(100)$ \\
\hline & \multicolumn{6}{|c|}{$X^{2}=250.352(0.000) ;$ Correlation coefficient $(R)=0.543(0.000)$} \\
\hline \multicolumn{7}{|c|}{ Discussed issues on social media } \\
\hline $\begin{array}{l}\text { Women civil and } \\
\text { political rights }\end{array}$ & $66(75.0)$ & $5(5.7)$ & $0(0)$ & $3(3.4)$ & $14(15.9)$ & $88(100)$ \\
\hline Women economic rights & $103(66.0)$ & $1(0.6)$ & $1(0.6)$ & $6(3.8)$ & $45(28.8)$ & $150(100)$ \\
\hline Women social rights & $32(72.7)$ & $0(0)$ & $1(2.3)$ & $5(11.4)$ & $6(13.6)$ & $44(100)$ \\
\hline Women cultural right & $145(78.0)$ & $1(0.5)$ & $3(1.6)$ & $12(6.5)$ & $25(13.4)$ & $186(100)$ \\
\hline Others & $71(78.0)$ & $0(0)$ & $1(1.1)$ & $5(5.5)$ & $14(15.4)$ & $91(100)$ \\
\hline
\end{tabular}

\section{Discussion of findings on e-advocacy}

The result of this study reveals that e-advocacy is seen to be the most effective tool and within the e-advocacy tool or categories, social media was chosen as the most effective and appropriate tools for the promotion and protection of women's rights. Similarly, Ify Bredan-Ndukwu of Women and Children's Rights Development Centre \{WOCHRID\} also views each of the advocacy tools as effective. She argued that "e-advocacy is faster and more effective in reaching a greater number of people but the limitation is that majority of Nigerians are illiterate and cannot appreciate this method of advocacy". 
Her concern about the effectiveness of e-advocacy is further amplified by the issues around access, availability, affordability of data and the challenge of poverty and gender digital divide. A study by Paradigm Initiative Nigeria (PIN) in conjunction with World Wide Web Foundation (WEB) (2015) on women's rights online affirmed the concern around access, availability and affordability. The study reveal that $67 \%$ of women in Lagos are unable to afford a $1 \mathrm{~GB}$ data plan and only $36 \%$ of poor women in Lagos use the internet(PIN and WEB, 2015).

The study further revealed that women are 50\% less likely than men to be online and $30-50 \%$ less likely to use the internet for economic and political empowerment. The implication of this is that e-advocacy mechanism that target women's rights online are not likely to meet these women's needs because they are offline. Hence, Gbenga Sesan digital rights activist and Executive Director of PIN opined that "the major limitation of e-advocacy is that a large part of advocacy is offline. Advocates who fail to combine e-advocacy and offline and physical contact enabled advocacy ultimately fail." Consequently, Toyin Oloniteru, a cyber-crime expert opined that:

\begin{abstract}
"e-advocacy should be limited to the privilege group of women with online access. What is the point of e-advocacy to the offline and unconnected women groups? We should implement government broadband policy programs and promote the universal access and services objectives as provided for in the National Communications Act, 2003, it Universal Services Provision Funds (USPF) provisions, the Universal Services and Access Regulations, etc. and the various school access programs, etc. women rights groups should key into the above."
\end{abstract}

In a focus group discussion with five participants comprising of three females and two males who identify themselves (self-describe) as people involved in technology provision (ICT), one of the participant pointed out that "e-advocacy offers a lot of opportunities to create awareness, connect women across borders and create a virtual sisterhood through which women share their wisdom, allay their fears and encourage one another." It can also be a tool for fighting for justice for women whose rights have been violated. They all pointed to cases where use of hashtags have help highlight women's plight from the \#Bringbackourgirls (BBOG) to reawaken \#metoo campaign which is helping women to highlight the cases of rape and sexual harassment around the world. The \#menaretrash campaign that started in South Africa to the \#freeSonde campaign. While this group of participants express much optimism about e-advocacy, the reality of women's experiences online undermine the 'manic optimism' of the first group of FDG discussants.

The second group of FGD participants were not entirely as optimistic as the first group. Although they share some benefits of e-advocacy with regards to how it has been useful in creating awareness, mobilising support, educating and sustaining the momentum on women related concerns from domestic violence, rape, girls education to gender pay gap, gender parity in governance to mention a few but they also highlighted the increase in violence against women online through, cyberbullying, cyberstalking and body shaming of women which makes many women stay off the internet. Added, to this, is the increasing massive government surveillance of citizens' activities online and the indiscriminate arrest of citizens which further poses more challenges to E- advocates. Responding to the challenge of internet freedom and its implication on women's rights, the lack of institutional capacity and the underdeveloped technological capacity of most 
institutions in Nigeria, particularly the law enforcement agents to protect women's rights online, Gbenga Sesan opined that

"Given the spate of numerous arrests of Nigerian citizens for comments made
online in the past two years (2016-2017), despite the availability of laws which
protect human rights online (such as the Constitution), the only hope for the
defence of women's rights online is in the continued advocacy by digital rights
advocates for the respect of the rule of law. Law enforcement agencies must
refuse to selectively interpret the law in the service of their paymasters. The
historic perception of the rights of women in Nigeria too has to be challenged,
because how women are perceived offline is what spills online (2017)."

Furthermore, contrary to the concern of the second group of FGD informants about massive surveillance as a challenge to e-advocacy Toyin Oloniteru opined that the claim about citizen privacy and freedom of expression online is a smear campaign by opposition on the current administration. In his words:

"Where is the federal government massive surveillance on citizens online? Our
government is still trying to achieve $30 \%$ broadband access! I consider such
allegations to be fake news. Where is the infrastructure (network, facilities,
people, processes, procedures, policies, software, hardware etc) installed or
available to do massive surveillance? (2017)."

The above highlighted mixed reaction about effectiveness and benefits of e-advocacy as a tool for promoting women's rights is further exacerbated by the fact that the internet is not the first course of resource for most women. The PIN \& WWF report earlier mentioned asserts that "Only $10 \%$ of women internet users had ever searched for information on sexual and reproductive health online, while $19 \%$ have looked for a job using online portals or information about women's health, rights and other." More so "services that promote women's well-being is lacking online. Most websites are in English, and many women with limited education are unlikely to benefit. Just $2 \%$ of women have access to mobile financial services." The implication is that most women are unlikely to participate and benefit from online activism. It is within this context that one of the participants involved in the second FGD argued that e-advocacy is elitist as it can only involve women who have the internet access and for women who affordability of $1 \mathrm{G}$ data is a luxury. It is however important to stress that, the argument of the second FGD is not to discredit or diminish the effectiveness of e-advocacy but a perspective necessary to balance the optimism of the first group of FGD with reality of women's experience. Toyin Oloniteru also noted that "the limitations of e-advocacy are lack of or inadequacies of technology infrastructure, high illiteracy levels and digital education pedagogy inadequacies among advocates." Added to this is the:

the proliferation of intellectual technicians within the e-advocacy space. Intellectual technicians are those not properly trained or structured in a subject matter and claiming to be experts there. The other is how to gettop level government buy-in with the political will to create enabling environment for e-advocacy exercises and activities.

Despite the limitations Gbenga Sesan noted that "technology, such as social media, have greatly reduced some of the traditional costs of running NGOs, such as communications costs". To curb violence against women online and the limitation to e-advocacy, Oloniteru offered the following suggestions. 
- Getting this privileged group of women properly educated and informed on cyberspace issues-its benefits, challenges and the attributes that amount to online violence.

- Educating this privileged group of women on ethics and good moral behaviours online e.g., soliciting for help from remotely unknown persons within or outside their jurisdictions (same or opposite sex), trying to exploit such unknown persons financially.

- Educating this privileged group of women on cybercrime especially the Cybercrime Prohibition and Prevention Act (CPPA) 2015 of the Federal Republic of Nigeria; the Nigeria Anti Terrorism Law and relationship with the CPPA, the ngCERT (Nigeria Emergency Response Team) in the Office of the National Security Adviser (ONSA).

- Educating this privileged group of women on how and who to report online violence acts to-security agencies, non-governmental organisations and other government agencies, etc;

The significance of this is that it provides a digital map for stakeholders in women's rights project to know where to concentrate their advocacy to garner more support for women's rights promotion and protection. The concept of digital mapping draws on analysis of internet behaviour of users to explain where internet users are most engaged and active online vs. where they are less engaged and active. Prensky (2001) was the first to develop label to explain internet behaviour to mark the distinction of people who are entirely at ease within the digital space who he tagged as 'digital native' and those who manage to exist in the virtual world which he tag as "digital immigrant". He writes:

"What should we call these 'new' students of today? Some refer to them as the $\mathrm{N}$ - [for Net]-gen or D-[for digital]-gen. But the most useful designation I have found for them is Digital Natives. Our students today are all 'native speakers' of the digital language of computers, video games and the internet. So what does that make the rest of us? Those of us who were not born into the digital world but have, at some later point in our lives, become fascinated by and adopted many or most aspects of the new technology are, and always will be compared to them, Digital Immigrants."

This terminology digital immigrant and native have been used until debates about its accuracy, appropriateness and disadvantage was highlighted by critics. One of the disadvantages of Prensky's analogy was that his analysis fails to consider context, motivation and is redundant in today's world since his analysis pre-dates the launch of what are now commonly known as social media applications. Particularly, Bennett, Maton, and Kervin, (2008) argue that Prensky framework is:

\footnotetext{
“...limited in scope and focus, the research evidence to date indicates that a proportion of young people are highly adept with technology and rely on it for a range of information gathering and communication activities. However, there also appears to be a significant proportion of young people who do not have the levels of access or technology skills predicted by proponents of the digital native idea. Such generalisations about a whole generation of young people thereby focus attention on technically adept students. With this comes the danger that those less interested and less able will be neglected, and that the potential impact of socio- economic and cultural factors will be overlooked. It may be that there is as much variation within the digital native generation as between the generations."
} 
Similarly, Margaryan and Littlejohn (cited in White and Le Cornu, 2011) opines:

"Many young students are far from being the epitomic global, connected, socially networked technologically-fluent digital native who has little patience for passive and linear forms of learning. While the use of technologies is limited in terms of the range and the nature, there is some evidence that younger students use some tools more actively than the older students, but neither of these two groups uses these technologies to support their learning effectively. Educators therefore cannot presume that all young students are 'digital natives' who understand how to use technology to support and enhance their learning (2008, p.22)."

The criticism of Prensky's framework led to the 'Visitors' and 'Residents' framework proposed by White and LeCornu (2011) as replacement to Prensky's digital native vs. digital immigrant framework (see Figure 1).

Figure 1 'Visitors' and 'Residents' framework (see online version for colours)

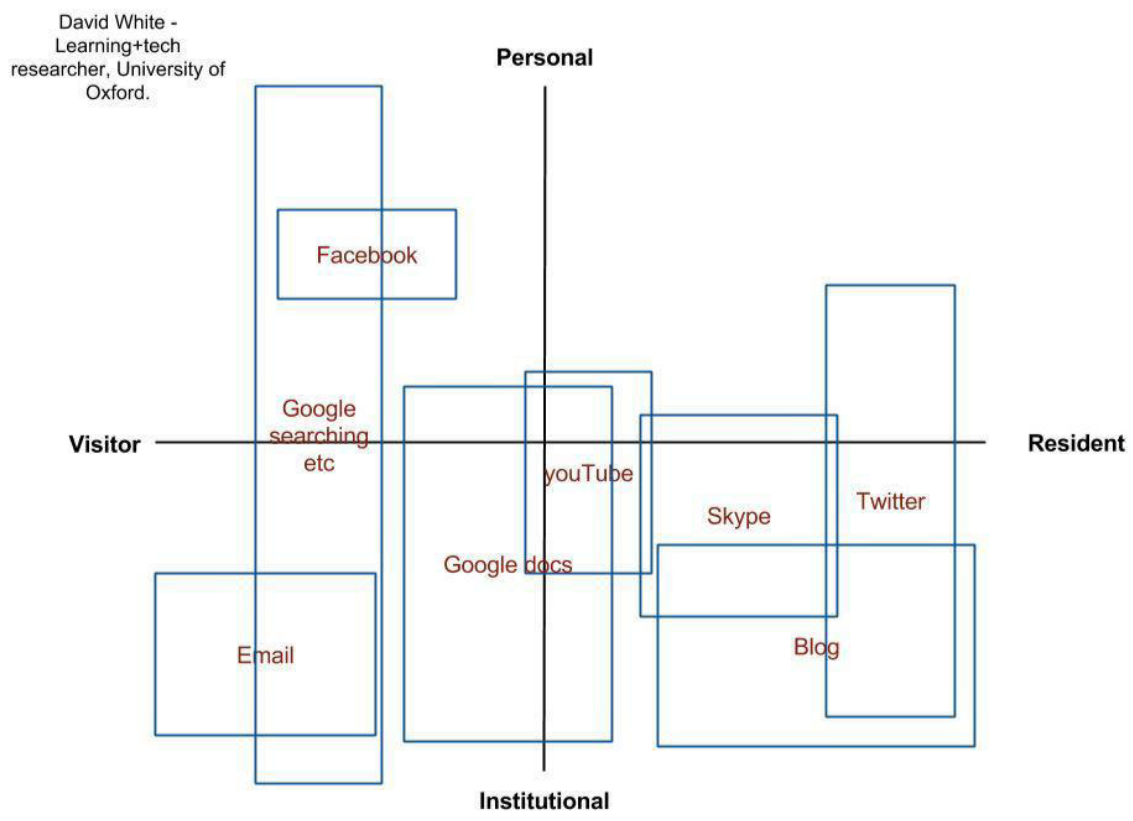

Source: White and Le Cornu (2011)

Unlike Prensky's framework, White and Le Cornu (2011) proposed looking at virtual engagement from the point of resident and visitor as opposed to comparing engagement to native and immigrant. At the core of the resident and visitor spectrum is motivation and the task to be done. In other words, place, tools and task are significant tool of analysing internet engagement rather than competence, age and cognitive ability. Internet users are able to incorporate questions such as: 'What am I going there for?', 'What am I hoping to achieve?', 'Which place best serves my purpose?', and 'How long do I intend to stay?', 'Have I got the skills that I need?' and 'Am I happy to be on my own, or would I prefer to be in company?' to determine whether they are visitors or residents paradigm in specific digital space (White and Le Cornu, 2011). 
The usefulness of digital map that the findings of the study provide for stakeholders involved in women's rights issues is that it allows for strategic planning, organisation and effective mobilisation to gain online support for women's rights cause they advocate for and where to engage the public more in the social media. The implication of these findings is that NGOs may need to blog less and generate less listserv but rather it could mean that they need to engage more social media applications like Facebook, Instagram and Twitter. Justification of the use of e-advocacy as the most effective can be explained by the liberalisation of the telecommunication sector which allow internet service providers (ISP) to emerge that competitively wants to gain the large market that Nigeria offer and serve the teeming population. Also, one can rationalise the justification for increasing use of e-advocacy tool to the proliferation of phones, smart phones and internet software that allow people to connect to one another thus closing the gap between space, time and distance.

However, it is pertinent to note that while e-advocacy is deemed effective and so much is said about the globalisation of the world via the instrument of technology, the question of access, affordability, availability and digital divide still remain a major barrier to the maximisation of the benefits that e-advocacy offers. The digital divide has widened the gap between those who have access to information, internet, communication technology and those who do not have despite the claim of a world flattened by the force of technology. Factors such as race, income, gender, age and geopolitics affect access, availability and affordability of internet in developing countries and Nigeria inclusive. Affordability is still a challenge for many people in Nigeria due to the slow pace of policy and regulatory progress (alliance for affordable internet (A4AI). According to (A4AI) 2017 reports, Nigeria ranks 13th (out of 58 countries surveyed) on the 2017 Affordability Drivers Index (ADI). This is a decrease from the 12th place ranking Nigeria earned in the 2015-2016 Report. Also, the question of safety for women online as well as its impact on their wellbeing largely remains a concern. Studies by Fardouly and Vartanian (2015), Tiggemann and Miller (2010), Tiggemann and Slater (2013), Fardouly, Diedrichs et al. (2015) have found positive correlations between Facebook usage and women's body dissatisfaction. Similarly, Nwammuo, (2013) found Facebook to be avenue for perpetuation of violence against women. Also, the virtual space has become the place for cyberbullying, body shaming, harassment and stalking of women online. This is exacerbated by the increasing pace of cybercrime and using information shared in virtual space to attack or gain access to people's financial details online with a view to fleecing them.

However, contrary to these concerns, $312(84 \%)$ respondents in this study, agree to the claims that e-advocacy is reducing incidents of women's rights violation and $156(\%)$ strongly agree that it is effective in highlighting the incidents of women's rights violation. More so, while e-advocacy has its advantages, its downsides necessitate the importance of synthesising online activism with offline action to incorporate the millions of people offline. Recognising the importance of e-advocacy does not imply that NGOs will discontinue their traditional advocacy practice. It does suggest, however, that situations most NGOs will face in the future will require new knowledge and technological skills such as using social software to increase the electronic advocacy capabilities of nonprofit organisations.

Furthermore, while the study corroborates earlier studies like Oyesomi, Okorie, Omole and Smith (2014), on the use of social media particularly Facebook by women, and Sesan's, (2006) study of the use of technologies by NGOs, 239 (38.9\%) of 
respondents in this study agree that NGOs are effectively using e-advocacy. However, it is contradictory to some earlier studies in the following ways. Previous studies find a gender dimension to internet access, availability, affordability and engagement online which ultimately affect the extent e-advocacy is used by women. Alliance for affordable internet(A4AI) World Wide Web Foundation, Paradigm Initiative Nigeria have found a gender digital divide in term of access, affordability, availability and level of engagement between men and women, while this study did not test all of the parameters, the study points of distinction in terms of level of engagement differ from previous studies as majority of the respondents who are women use internet always and use it for the promotion of women's cultural rights among other forms of women's rights (See Table). This difference between this study and previous studies does not in any way invalidate preceding and ongoing studies, it suggests that context, class, education, employment status matter in the application of e-advocacy. However, despite all the support for e-advocacy, its visibility and success in highlighting social change and the extent to which women's online activism has been able to shape and influence policy making remains patchy and unpredictable (Loiseau and Nowacka, 2015).

This study contradicts existing studies, statistics and reports. This study revealed that there are more women online and more are engaged in digital activism for womencentred issues. $74 \%$ of women with the minimum educational qualification of a bachelor's degree are online, with $93 \%$ of these always online. Meanwhile, a study by Paradigm Initiative Nigeria (PIN), in conjunction with World Wide Web Foundation (WEB) (2015) found that women are 50\% less likely than men to be online and $30-50 \%$ less likely to use the internet for economic and political empowerment. The study further revealed that $67 \%$ of women in Lagos are unable to afford a $1 \mathrm{~GB}$ data plan and only $36 \%$ of poor women in Lagos use the Internet (PIN and WEB, 2015). The study indicated that women's digital activism could be impeded by issues around access, availability and affordability. This discrepancy is not to suggest that the study is invalid, but it suggests that location, class, and education matter in studies on women's digital activism. Affordability is still a challenge for many people in Nigeria due to the slow pace of policy and regulatory progress (alliance for affordable internet (A4AI)).

Furthermore, while this study reveals that digital activism has been useful in highlighting social issues, particularly, those that are centred on women's rights, it also contradicts other studies by revealing that it has not been effective in driving social change. In other words, digital activism has been helpful in the promotion of womencentred issues, but not in the protection of them. Promotion emphasises recognition, but recognition does not always translate into protection (enforcement or social change). Recognition is a political act by which the recognising state indicates its willingness to take effective measures towards 'reforming' or domesticating its legal system to reflect the provisions of the international legal framework which the country is a signatory to (Holt, 1991; Adolfo, 2010). However, enforcement requires greater commitment in form of empowerment of the judiciary and executive through the provision of tools, resources, and capacity to enforce the law. Adolfo (2010) further suggests that recognition usually means a possibility for legal reform and the willingness of states to enter into official dialogue, but it does not mean commitment to changing internal structures to accommodate and enforce the law. Simply, states' protection connotes increasing awareness or highlighting social issues, while protection denotes the extent of real change in the social issues. No issues affirm this power of digital activism to promote womencentred issues and not its protection other than the two kidnap cases (Chibok girls and 
Dapchi girls) in Nigeria between 2014-2018. No doubt, digital activism helped to raise the profile of these issues and led to increasing efforts and pressure on the government to secure the release of the girls, yet it has not translated into the release of all the girls.

In addition, while this study revealed that most respondents engage online with activism on women-centred issues and discuss women-centred issues, which no doubt has raised the profile of such issues, the impact of their digital activism on social change for the lives of women is still debatable when compared with international benchmarks. For instance, the United Nations Development Programme (UNDP) Human Development Index (HDI) (2016) specifically reported that Nigeria ranked 157 out of 188 countries in the Gender Inequality Index, compared with Botswana that ranked 106, São Tomé and Príncipe placed at the 143rd position, Ghana, 139th position and Kenya occupying the 145 th position.

The implication of the already-mentioned contradictions and complexities around digital activism on women-centred issues suggest that there is more to digital activism. Digital activism is complex, and its success or failure is dependent on several factors. Hence, digital activism should be measured in terms of individual cases of activism (e.g., \#FindShonde which culminated in justice for the victim) and not collective issues which are more complex and involve more actors (\#BBOG \#DapchiGirls and \#FreeLeahSharibu). In other words, we can only measure the success or failure of digital activism on the bases of the context and each peculiar case. The BBOG was a complex case, involving a collective group, that is a group of girls as against the individual case of \#FindShonde. It was intertwined with religious, political, cultural and state factors. The actors in the BBOG case were also complex, there was the state, the insurgent group, the girls in question, the Nigerian public, the international community, and the alleged foreign sponsors of the group. The implication of this is that the capacity of digital activism to translate to social change or slacktivism is beyond citizens' engagement with digital activism, but dependent on a variety of other factors. Simply put, much is required before digital activism can translate to social change, hence, a combination of digital activism, traditional activism and other forms of advocacy is required for activism to translate to social change.

\section{Conclusion}

The paper examined the effectiveness of e-advocacy as a tool for promoting women's rights in Lagos and Ogun state. The study found mixed reactions about effectiveness and benefits of e-advocacy as a tool for promoting women's rights. Others find it limited, distracting to offline activism and elitist in nature. The perception of its elitism draws on the high levels of illiteracy which then mean that many women with limited education are unlikely to participate and benefit from online activism, poverty, gender digital divide and the challenge of internet skill, access, and affordability. The latter argument is sustained by a study by PIN on women's rights online which affirmed that $67 \%$ of women in Lagos are unable to afford a $1 \mathrm{~GB}$ data plan and only $36 \%$ of poor women in Lagos use the internet. This reality is exacerbated by the increase in violence against women online, cyberbullying, cyberstalking and body shaming of women online. Given these realities, the study recommends among others the necessity of recognising the strength of e-advocacy while balancing the limitations with offline activism and the need 
for legal framework that protect women's rights online and reform of the Cybercrime Act to criminalise harassment or other violence against women online

\section{References}

Adolfo, S. (2010) 'The recognition of the human rights of African women', Int'l J, Advanced Legal Stud. and Governance, Vol. 1, No. 1, pp.29-41.

Aleyomi, M.B. and Ajakaiye, O.P. (2012) 'The impact of social media on citizens' mobilization and participation in Nigeria's 2011 General elections', Centrepoint Journal, Vol. 17, No. 2, pp.31-52.

Bennett, S., Maton, K. and Kervin, L. (2008) 'The', 'Digital Natives' Debate: A Critical Review of the Evidence British Journal of Educational Technology, Vol. 39, No. 5, pp.775-786, http://dx.doi.org/10.1111/j.1467-8535.2007.00793.x

Breuer, A. and Farooq, B. (2012) Online Political Participation: Slacktivism or Efficiency Increased Activism? Evidence From the Brazilian Ficha Limpa Campaign. Evidence from the Brazilian Ficha Limpa Campaign (1 May, 2012).

Budish, R.H. (2012) 'Click to change: optimism despite online activism's Unmet expectations', Emory Int'l L, Rev., Vol. 26, p.745.

Dunu, I.V. and Uzochukwu, C.E. (2015) 'Social media: an effective tool for social mobilization in Nigeria', IOSR Journal of Humanities and Social Science (IOSR-JHSS), Vol. 20, pp.10-21.

Emma, O.U. (2015) 'The hashtag as a channel of international communication: a study of the \#Bringbackourgirls hashtag', Communication Panorama African and Global Perspectives, Vol. 1, No. 1, pp.1-13.

Fardouly, J. and Vartanian, L.R. (2015) 'Negative comparisons about one's appearance mediate the relationship between Facebook usage and body image concerns', Body Image, Vol. 12, pp.82-88, http://dx.doi.org/10.1016/j.bodyim.2014.10.004

Fardouly, J., Diedrichs, P.C., Vartanian, L. and Halliwell, E. (2015) 'Social comparisons on social media: the impact of facebook on young women's body image concerns and mood', Body Image, Vol. 13, pp.38-45. Available from: http://eprints.uwe.ac.uk/24574

Gay, R. (2013) Looking for a Better Feminism, Retrieved from http://www.npr.org/blogs/ codeswitch/2013/08/22/214525023/twitter-sparks-a-serious-discussionabout-race-andfeminism

Goldberg, M. (2014) Feminism's Toxic Twitter Wars, Te Nation, Retrieved from http://www. thenation.com/article/178140/feminisms-toxic-twitter-wars

Harlow, S. and Guo, L. (2014) 'Will the revolution be tweeted or facebooked? using digital communication tools in immigrant activism', Journal of Computer-Mediated Communication, Vol. 19, No. 3, pp.463-478.

Holt, R. (1991) 'Women's rights and international law: the struggle for recognition and enforcement. Columbia', Journal of Gender and Law, Vol. 1, pp.117-128.

Kalyango Jr., Y. and Adu-Kumi, B. (2013) 'Impact of social media on political mobilization in East and West Africa', Global Media Journal, Vol. 12, No. 22, pp.1-20.

Lewis, K., Gray, K. and Meierhenrich, J. (2014) 'The structure of online activism', Sociological Science, Vol. 1, pp.1-9.

Lim, M. (2012) 'Clicks, cabs, and coffee houses: social media and oppositional movements in Egypt, pp.2004-2011', Journal of Communication, Vol. 62, No. 2, pp.231-248.

Loiseau, E. and Nowacka, K. (2015) Can Social Media Effectively Include Women's Voices in Decision-Making Processes?, Paris, France.

Morozov, E. (2011) The Net Delusion: The Dark Side of Internet Freedom, Perseus Books Group.

Murphy, M. (2013) The Trouble with Twitter Feminism, from http://feministcurrent.com/8403/thetrouble-with-twitter-feminism/ 
Newsom, V.A. and Lengel, L. (2012) 'Arab women, social media, and the Arab spring: applying the framework of digital reflexivity to analyze gender and online activism', Journal of International Women's Studies, Vol. 13, No. 5, pp.31-45.

Nwammuo, A.N. (2013) 'Social media and perpetuation of violence against women in Nigeria: The case of facing death on Facebook', AFRREV LALIGENS: An International Journal of Language, Literature and Gender Studies, Vol. 2, No. 2, pp.1-10.

Okoro, N. and Nwafor, K.A. (2013) 'Social media and political participation in Nigeria during the 2011 general elections: the lapses and the lessons', Global Journal of Arts Humanities and Social Sciences, Vol. 1, No. 3, pp.29-46.

Outshoorn, J. (2012) 'Assessing the impact of women's movements', Women's Studies International Forum, Vol. 35, No. 3, pp.147-149, Pergamon.

Oyesomi, K., Okorie, N., Omole, F. and Smith, A. (2014) 'How sociable are women on social media? An experiential study on Nigerian women', International Journal of Research in Social Sciences, Vol. 4, No. 2, p.57.

Sara, A. (2015) 'Digital activism for women's rights in the Arab world', Upholding Gendered Peace at a Time of War Conference, Beirut, Lebanon.

Saxton, G.D., Niyirora, J.N., Guo, C. and Waters, R.D. (2015) '\#AdvocatingForChange: The strategic use of hashtags in social media advocacy', Advances in Social Work, Vol. 16, No. 1, pp.154-169.

Scott, J.T. and Maryman, J. (2016) 'Using social media as a tool to complement advocacy efforts', Global Journal of Community Psychology Practice, Vol. 7, No. 5, pp.1-22.

Sesan, G. (2006) 'Research on e-advocacy and technology used by civil society in Nigeria', in Tactical Tech Strategy Paper (2011) Prospect of E-advocacy in Global South.

Sivitanides, M. and Shah, V. (2011) 'The era of digital activism', in Conference for Information Systems Applied Research, Vol. 4, No (1842).

Tiggemann, M. and Miller, J. (2010) 'The internet and adolescent girls' Weight Satisfaction and Drive For thinness. Sex Roles, Vol. 63, pp.79-90 http://dx.doi.org/10.1007/s11199-010-9789-z

Tiggemann, M. and Slater, A. (2013) 'NetGirls: The internet, facebook, and body image concern in adolescent girls', International Journal of Eating Disorders, Vol. 46, pp.630-634, http://dx.doi.org/10.1002/eat.22141

Tufekci, Z. and Wilson, C. (2012) 'Social media and the decision to participate in political protest: observations from Tahrir square', Journal of Communication, Vol. 62, No. 2, pp.363-379.

United Nations Development Programme (UNDP) (2016) Gender Inequality Index, Accessed on 25th August 2017 from http://hdr.undp.org/en/composite/GII

White, D.S. and Le Cornu, A. (2011) 'Visitors and residents: a new typology for online engagement', First Monday, Vol. 16, No. 9, Published on 5 September 2011, http:// firstmonday.org/ojs/index.php/fm/article/view/3171/30 